\title{
PENGARUH QUALITY OF WORK LIFE TERHADAP MOTIVASI KERJA DAN KEPUASAN KERJA KARYAWAN
}

\author{
Ni Luh Putu Surya Astitiani ${ }^{(1)}$ \\ Ida Bagus Ketut Surya ${ }^{(2)}$ \\ ${ }^{(1)(2)}$ Fakultas Ekonomi dan Bisnis Universitas Udayana, Bali - Indonesia \\ e-mail:ani_astiti@yahoo.com
}

\begin{abstract}
ABSTRAK
Penelitian ini bertujuan untuk mengetahui pengaruh Quality of Work Life terhadap Motivasi Kerja dan Kepuasan Kerja Karyawan. Penelitian dilakukan di Swastika Bungalows Sanur, dengan sampel sebanyak 60 orang karyawan yang diambil dengan metode sampel jenuh atau sensus. Teknik analisis data yang digunakan yaitu teknik analisis jalur (path analysis). Hasil penelitian menunjukkan bahwa semakin tinggi Quality of Work Life yang diterapkan maka semakin tinggi pula motivasi kerja karyawan yang berdampak pada peningkatkan kepuasan kerja karyawan dengan hasil analisis jalur yang menunjukan bahwa motivasi kerja berpengaruh positif dalam memediasi pengaruh Quality of Work Life terhadap kepuasan kerja karyawan sehingga, dari hasil penelitian ini dapat menjadi referensi bagi perusahaan untuk meningkatkan kesejahteraan karyawan melalui peningkatan keamanan kerja, memberikan kebebasan kepada karyawan, dan peningkatan dalam pemberian insentif bagi karyawan yang dapat berdampak pada peningkatan produktivitas perusahaan.
\end{abstract}

Kata kunci : quality of work life, motivasi kerja, kepuasan kerja

\begin{abstract}
This study aims to determine the effect on the Quality of Work Life Work Motivation and Job Satisfaction. The study was conducted at the Swastika Bungalows Sanur, with a sample of 60 employees who were taken with saturated or census sampling method. Data analysis technique used is the technique of path analysis (path analysis). The results showed that the higher the Quality Of Work Life applied by the company, the higher employee motivation that impact on enhancing employee satisfaction with the results of path analysis showed that motivation positive effect in mediating the effect of Quality Of Work Life on employee job satisfaction so , the results of this study can serve as a reference for the company to improve the welfare of employees through increased job security, giving freedom to employees, and increased the incentive for employees to have an impact on increasing the productivity of the company.
\end{abstract}

Keywords : quality of work life, work motivation, job satisfaction

\section{PENDAHULUAN}

Quality of Work Life merupakan salah satu faktor penting untuk motivasi manusia dan meningkatkan kepuasan kerja (Kermansaravi et al., 2015). Quality of Work Life (kualitas kehidupan kerja) adalah konsep yang komprehensif yang terdiri dari kesehatan fisik dan psikologis, situasi ekonomi, kepercayaan pribadi dan interaksi dengan lingkungan (Khorsandi et al., 2010). Suasana kerja akan menciptakan kualitas kehidupan kerja yang kondusif bagi tercapainya tujuan organisasi dimana peningkatan Quality of Work Life dapat memiliki dampak positif pada kepuasan kerja (Paseki, 2013). Hasil-hasil penelitian tersebut menyiratkan bahwa Quality of Work Life adalah cara yang tepat untuk meningkatkan kualitas sumber daya manusia dalam perusahaan. Dengan melalui suatu proses, sumber daya manusia (karyawan) akan lebih memaksimalkan tanggung jawab atas pekerjaan mereka (Aryansah dan Erika, 2013).
Banyak penelitian tentang Quality Of Work Life telah dilakukan dan hasilnya menunjukkan bahwa terdapat hubungan positif antara Quality $O f$ Work Life dengan beberapa variabel dalam organisasi seperti motivasi kerja dan kepuasan karyawan (Fitriadi, 2012). Rokhman (2012) dalam penelitiannya juga membuktikan bahwa terdapat pengaruh yang positif antara Quality Of Work Life dengan kepuasan kerja, yang dapat diartikan semakin tinggi Quality Of Work Life seorang karyawan maka semakin tinggi pula kepuasan kerjanya. Hasil penelitian lainnya juga mengungkapkan hubungan Quality Of Work Life dan kepuasan kerja pada pegawai organisasi pemerintahan di Iran, dimana dikatakan bahwa penerapan kualitas kehidupan kerja yang baik akan meningkatkan kepuasan kerja karyawan (Nekouei,et.al, 2014).

Pimpinan Swastika Bungalows Sanur mengatakan bahwa, produktivitas karyawan 
mengalami fluktuasi, disebabkan karena penempatan karyawan yang tidak sesuai dengan skill karyawan. Penempatan karyawan yang salah berdampak pada rendahnya tingkat disiplin karyawan yang dapat dilihat dari rendahnya kepatuhan akan jam kerja, kurangnya perhatian akan tata tertib yang berlaku dan tingginya tingkat penundaan pekerjaan karyawan. Pimpinan Swastika Bungalows Sanur juga menjelaskan bahwa tingkat persentase kehadiran karyawan cukup tinggi namun tidak sebanding dengan kedisiplinan di mana karyawan pulang lebih awal dari jam kerja yang telah ditetapkan Swastika Bungalows Sanur.

Belum ada penelitian yang pernah dilakukan mengenai pengaruh Quality Of Work Life terhadap kepuasan kerja karyawan secara langsung di Swastika Bungalows Sanur dan belum ada penelitian yang pernah dilakukan mengenai pengaruh Quality Of Work Life terhadap kepuasan kerja karyawan secara tidak langsung melalui motivasi kerja karyawan di Swastika Bungalows Sanur. Penelitian ini dilakukan untuk mengetahui pengaruh Quality Of Work Life terhadap kepuasan kerja karyawan dan untuk mengetahui pengaruh Quality of Work Life terhadap kepuasan kerja karyawan yang dimediasi oleh motivasi kerja karyawan di Swastika Bungalows Sanur.

Kepuasan kerja karyawan merupakan faktor penting yang menentukan kesuksesan suatu organisasi (Teck-Hong dan Waheed, 2011). Veithzal Rivai \& Deddy Mulyadi (2011: 247) menyatakan bahwa "Ada beberapa faktor yang dapat menimbulkan kepuasan kerja seseorang, antara lain: kedudukan, pangkat atau jabatan, masalah umur, jaminan finansial dan jaminan sosial, serta mutu pengawasan". Murtiningrum (2011), menyatakan bahwa kepuasan kerja adalah sikap umum terhadap pekerjaan seseorang, yang menunjukan perbedaan antara jumlah penghargaan yang diterima pekerja dan jumlah yang mereka yakini seharusnya mereka terima. Kepuasan kerja adalah bagaimana orang melaksanakan pekerjaan dan aspek-aspeknya (Arifin, 2012).
Quality Of Work Life adalah suatu cara pikir tentang orang-orang, pekerjaan, dan organisasi yang memusatkan perhatian pada dampak pekerjaan terhadap pekerja dan efektivitas organisasional, disamping memberikan gagasan-gagasan partisipatif dalam memecahkan masalah-masalah organisasional dan pembuatan keputusan (Anatan dan Ellitan, 2007:74). Quality Of Work Life merupakan cerminan perasaan karyawan terhadap pekerjaannya, termasuk dampak dari pekerjaaan tersebut terhadap kesejahteraan karyawan (Umstot dalam Idrus, 2006). Chandranshu Sinha (2012) terdapat dua belas faktor penting dari Quality of Work Life untuk pengembangan karyawan seperti komunikasi, pengembangan karir dan pertumbuhan, komitmen organisasi, dukungan pengawasan emosional, pengaturan kerja yang fleksibel, budaya respon keluarga, motivasi karyawan, iklim organisasi, dukungan organisasi, kepuasan kerja, penghargaan dan manfaat dan kompensasi.

Robbins dan Timothy (2013) mendefinisikan motivasi sebagai proses yang menjelaskan intensitas, arah dan ketekunan usaha untuk mencapai suatu tujuan. Seseorang bekerja karena didorong oleh keinginan untuk dapat memenuhi kebutuhannya, sedangkan perusahaan selalu mengharapkan agar karyawannya bekerja dengan baik karena dengan cara tersebut perusahaan dapat mencapai tujuannya dengan hasil sesuai harapan perusahaan. Motivation adalah suatu dorongan atau menggerakan dimana dalam manajemen motivasi hanya ditujukan kepada sumber daya manusia dengan mempersoalkan bagaimana cara mengarahkan daya dan potensi karyawan agar dapat bekerja dengan baik sehingga tujuan perusahaan dapat tercapai sesuai dengan tujuan perusahaan (Sunyoto, 2013).

Berdasarkan pada kajian pustaka dan hasil-hasil penelitian terdahulu, maka model konseptual penelitian dapat digambarkan seperti pada Gambar 1.

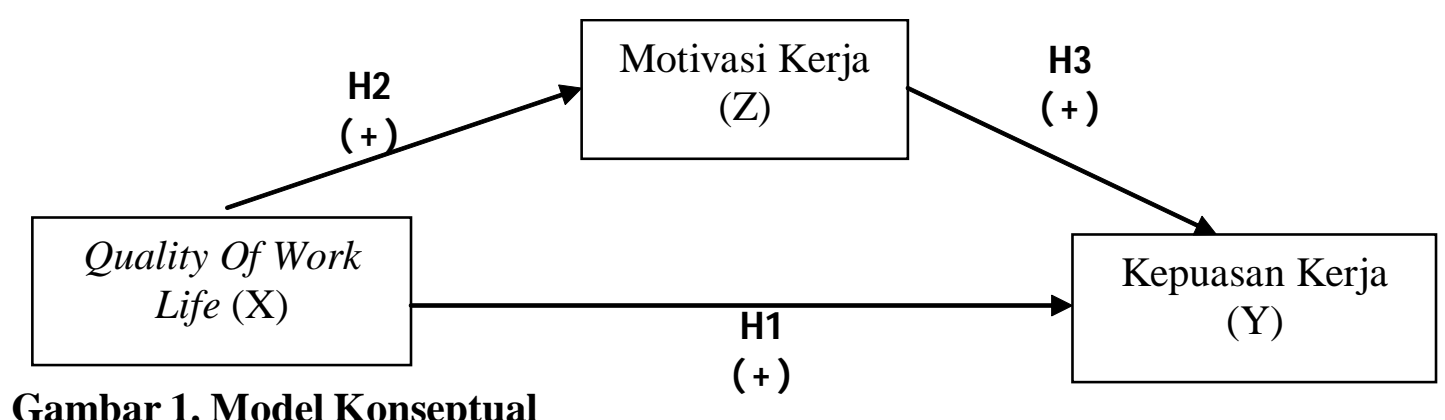

Gambar 1. Model Konseptual 
Pengaruh Quality Of Work Life (QWL) terhadap Job Statisfaction diperoleh hasil regresi bernilai positif dan signifikan dimana dengan meningkatkan Quality Of Work Life (QWL) maka akan berpengaruh terhadap peningkatan kepuasan kerja karyawan (Pramdhana, 2013). Kepuasan kerja dapat meningkat diimbangi dengan meningkatnya kondisi kerja, kesejahteraan umum, keseimbangan kehidupan kerja dan prospek karir, kompensasi serta pelatihan dan pengembangan (Swapna \& Gomathi, 2013). $\mathrm{H}_{1}$ : Quality Of Work Life berpengaruh positif terhadap Kepuasan kerja karyawan.

Quality Of Work Life berpengaruh secara signifikan terhadap motivasi kerja yang dibuktikan dengan hasil penelitian diketahui bahwa secara simultan dimensi Quality Of Work Life yang meliputi partisipasi dalam pengambilan keputusan variabel restrukturisasi kerja, variabel sistem imbalan yang inovatif, dan variabel lingkungan kerja berpengaruh secara signifikan terhadap variabel motivasi kerja (Yasa, 2007). Secara keseluruhan Quality Of Work Life berpengaruh langsung dan signifikan terhadap motivasi kerja dimana Quality Of Work Life yang baik akan meningkatkan motivasi kerja dan kinerja pekerja dan diharapkan setiap pekerja mau bekerja keras dan antusias untuk mencapai produktivitas kerja yang tinggi (Aryansah, 2012).

$\mathrm{H}_{2}$ : Quality Of Work Life berpengaruh positif terhadap Motivasi kerja.

Teori Hierarki Kebutuhan dari Maslow dalam buku Perilaku Keorganisasian mengemukakan bahwa manusia ditempat kerjanya dimotivasi oleh suatu keinginan untuk memuaskan sejumlah kebutuhan yang ada dalam diri seseorang (Rahmawati, 2013). Apabila pemberian motivasi tidak dilakukan, maka akan menimbulkan ketidakpuasan karyawan. Motivasi kerja berpengaruh secara signifikan terhadap kepuasaan kerja pegawai dimana untuk tetap mempertahankan dan terus meningkatkan motivasi pada pegawainya seperti pemenuhan kebutuhan dan keinginan yang sesuai harapan, fasilitas kerja terpenuhi, hubungan baik dengan rekan sekerja, serta keamanan di lingkungan kerja dalam menciptakan kepuasaan kerja yang lebih tinggi dari sebelumnya (Murti \& Srimulyani, 2013). $\mathrm{H}_{3}$ : Motivasi kerja berpengaruh positif terhadap Kepuasan kerja karyawan.

\section{METODE}

Penelitian ini dilakukan di Swastika Bungalows Sanur yang berlokasi di Jalan Danau Tamblingan No.150 Sanur, Denpasar Selatan. Populasi penelitian ini adalah seluruh karyawan Swastika Bungalows Sanur, sebanyak 60 orang. Sampel sebanyak 60 orang karyawan diambil dengan menggunakan metode sampel jenuh atau sensus.

Variabel yang digunakan dalam penelitian ini ada 3 variabel yaitu variabel Eksogen Quality of Work Life karyawan (X), variabel Endogen Kepuasan kerja karyawan (Y), dan variabel Pemediasi motivasi kerja karyawan ( $Z$ ). Penelitian ini berpendekatan kuantitatif, berjenis asosiatif. Penelitian asosiatif bertujuan untuk mengetahui pengaruh dua variabel atau lebih yaitu pengaruh variabel Quality of Work Life karyawan terhadap kepuasan kerja karyawan, Quality of Work Life karyawan terhadap motivasi kerja karyawan serta pengaruh motivasi kerja karyawan terhadap kepuasan kerja karyawan (Sugiyono, 2014:5).

Jenis data yang digunakan dalam penelitian ini adalah data kuantitatif dan kualitatif. Data kuantitatif yang dikumpulkan dalam penelitian ini adalah persentase tingkat kehadiran karyawan, jumlah karyawan dan tabulasi hasil kuesioner. Data kualitatif yang dikumpulkan dalam penelitian ini adalah data mengenai gambaran umum, struktur organisasi, dan hasil wawancara mengenai Quality Of work Life, motivasi kerja dan kepuasan kerja karyawan.

Penelitian dilakukan dengan metode pengumpulan data yaitu wawancara dengan mengadakan tanya jawab langsung kepada pimpinan dan karyawan sehingga mendapatkan data yang diperlukan untuk mengetahui masalah yang ada mengenai Quality Of Work Life, motivasi kerja dan kepuasan kerja karyawan dan menggunakan metode kuesioner dengan mengajukan daftar pertanyaan tertulis yang diajukan kepada karyawan mengenai variabel, Quality Of Work Life, motivasi kerja dan kepuasan kerja karyawan.

Sumber data yang digunakan adalah sumber data primer dan sekunder. Data primer dalam penelitian ini seperti gambaran umum perusahaan dan keluhan yang dirasakan karyawan. Data sekunder dalam penelitian ini seperti jumlah karyawan, struktur organisasi dan persentase tingkat kehadiran karyawan.

Pengujian Instrumen Penelitian ini menggunakan uji validitasi dan reliabilitas instrumen. Pengujian validitas dapat dilakukan dengan pengujian korelasi antar skor masing-masing item pernyatan dengan total skor sehingga diperoleh nilai pearson correlation. Pengujian reliabilitas menunjukan sejauh mana suatu pengukuran dapat memberikan hasil yang konsisten bila dilakukan pengukuran kembali. Pengujian validitas dan reliabilitas instrumen 
pada penelitian ini menggunakan program SPSS for windows 17.00.

Berdasarkan Tabel 1. dapat dilihat bahwa instrumen pada setiap variabel dalam penelitian ini menunjukan hasil skor total diatas 0,30 dengan menghasilkan korelasi terbesar adalah 0,823 yaitu variabel motivasi kerja dengan item indikator (Z.6) dan korelasi yang terkecil adalah 0,563 yaitu variabel Quality of Work Life dengan item indikator (X.1). Hasil uji validitas secara keseluruhan indikator dinyatakan valid dan dapat dilanjutkan ke analisa berikutnya.

Tabel 1. Hasil Uji Validitas Instrumen

\begin{tabular}{|c|c|c|c|c|}
\hline No. & Variabel & Item Pernyataan & $\begin{array}{c}\text { Korelasi Item } \\
\text { Total }\end{array}$ & Keterangan \\
\hline \multirow{6}{*}{1.} & \multirow{6}{*}{ Quality of Work Life } & $\mathrm{X} .1$ & 0.563 & Valid \\
\hline & & X.2 & 0.626 & Valid \\
\hline & & $\mathrm{X} .3$ & 0.623 & Valid \\
\hline & & $\mathrm{X} .4$ & 0.589 & Valid \\
\hline & & $\mathrm{X} .5$ & 0.739 & Valid \\
\hline & & X.6 & 0.748 & Valid \\
\hline \multirow{6}{*}{2.} & \multirow{6}{*}{ Motivasi Kerja } & Z.1 & 0.657 & Valid \\
\hline & & Z.2 & 0.710 & Valid \\
\hline & & Z.3 & 0.622 & Valid \\
\hline & & Z.4 & 0.756 & Valid \\
\hline & & Z.5 & 0.794 & Valid \\
\hline & & Z.6 & 0.823 & Valid \\
\hline \multirow{6}{*}{3.} & \multirow{6}{*}{ Kepuasan Kerja Karyawan } & Y.1 & 0.791 & Valid \\
\hline & & Y.2 & 0.713 & Valid \\
\hline & & Y.3 & 0.756 & Valid \\
\hline & & Y.4 & 0.720 & Valid \\
\hline & & Y.5 & 0.750 & Valid \\
\hline & & Y.6 & 0.761 & Valid \\
\hline
\end{tabular}

Sumber : Data diolah, 2015

Tabel 2. Hasil Uji Reliabilitas Instrumen

\begin{tabular}{lcc}
\hline \multicolumn{1}{c}{ Variabel } & Cronbach's Alpha & Keterangan \\
\hline Quality of Work Life (X) & 0.728 & Reliabel \\
Motivasi Kerja (Z) & 0.809 & Reliabel \\
Kepuasan Kerja Karyawan (Y) & 0.831 & Reliabel \\
\hline
\end{tabular}

Sumber : Data diolah, 2015

Berdasarkan Tabel 2, dapat dikatakan instrumen penelitian ini reliabel. Hasil uji reliabilitas menunjukan bahwa masing-masing nilai Cronbach's Alpha setiap instrument lebih besar dari 0,6 sehingga dapat digunakan untuk melakukan penelitian.

Teknik analisis yang digunakan pada penilitian ini berupa teknik analisis jalur (path analysis). Adapun langkah-langkah menggunakan teknis analisis jalur yaitu pertama membuat diagram jalur dari model penelitian, kedua membangun persamaan struktural. Hubungan antar variabel teoritis dapat dirumuskan kedalam model persamaan struktural yaitu: Persamaan substruktur 1

$$
\mathrm{Z}=\beta_{2} \mathrm{X}+e_{1}
$$

Persamaan substruktur 2

$$
\mathrm{Y}=\beta_{1} \mathrm{X}+\beta_{3} \mathrm{Z}+e_{2}
$$

\section{Keterangan:}

$\mathrm{X}=$ Quality Of Work Life

$\mathrm{Z}=$ Motivasi Kerja

$\mathrm{Y}=$ Kepuasan Kerja Karyawan

$\beta_{1}=$ Koefisien regresi variabel Quality Of Work Life berpengaruh terhadap variabel Motivasi Kerja

$\beta_{2}=$ Koefisien regresi variabel Quality Of Work Life berpengaruh terhadap Kepuasan Kerja Karyawan

$\beta_{3}=$ Koefisien regresi variabel Motivasi Kerja berpengaruh terhadap Kepuasan Kerja Karyawan

$\varepsilon_{1}=$ Error of term atau variabel pengganggu

$\varepsilon_{2}=$ Error of term atau variabel pengganggu 
Ketiga, pemeriksaaan validitas model menunjukan baik atau tidaknya suatu hasil analisis tergantung pada asumsi-asumsi yang melandasinya, indikator validitas model yang terdapat dalam path analysis adalah koefisien determinasi total dan theory trimming. Nilai Koefisien determinasi () digunakan untuk mengukur besarnya kontribusi variabel Quality Of Work Life dan Motivasi Kerja terhadap Kepuasan Kerja Karyawan serta untuk mengetahui ketepatan alat analisis data.

Keempat, pemeriksaan terhadap asumsi yang melandasi analisis jalur yaitu hubungan antar variabel adalah linier dan adiktif, serta model yang digunakan adalah recursive (aliran kausal satu arah). Kelima, meringkas dan menyimpulkan. Langkah terakhir adalah meringkas dan menyimpulkan hasil interpretasi, dimana koefisien yang signifikan adalah memperlihatkan besaran pengaruh langsung maupun tidak langsung dan menunjukkan variabel yang dominan, sedangkan koefisien yang tidak signifikan nilainya dianggap tidak ada.

\section{HASIL DAN PEMBAHASAN \\ Deskripsi Variabel Penelitian}

Dalam penelitian ini responden penelitian digambarkan dengan menyajikan karakteristik responden yang dilihat dari variabel demografi yaitu, jenis kelamin, usia, pendidikan terakhir dan lamanya bekerja.

Berdasarkan Tabel 3. dapat dikatakan bahwa responden dengan jenis kelamin laki-laki, usia 4150 tahun dan tingkat pendidikan terakhir SMA/ Sederajat serta responden dengan lamanya bekerja lebih dari 21 tahun mendominasi pada penelitian ini. Ini dapat dilihat dari hasil persentase pada Tabel 3. yaitu variabel demografi jenis kelamin, persentase jumlah responden laki-laki sebesar 73,33 persen. Berdasarkan usia responden, jumlah responden dengan usia 41-50 tahun yang mendominasi dengan persentase sebesar 31,67 persen. Berdasarkan tingkat pendidikan terakhir mayoritas responden dengan tingkat pendidikan terakhir adalah SMA/ Sederajat dengan persentase sebesar 63,33 persen. Berdasarkan variabel demografi lamanya bekerja, jumlah responden yang bekerja lebih dari 21 tahun yang mendominasi dengan persentase sebesar 40 persen.

Tabel 3.

Karakteristik Responden

\begin{tabular}{|c|c|c|c|c|}
\hline No. & Variabel & Klasifikasi & $\begin{array}{l}\text { Jumlah } \\
\text { (orang) }\end{array}$ & Persentase (\%) \\
\hline \multirow{3}{*}{1.} & \multirow[b]{2}{*}{ Jenis kelamin } & Laki-laki & 44 & 73.33 \\
\hline & & Perempuan & 16 & 26.67 \\
\hline & $\begin{array}{l}\text { Jumlah } \\
\end{array}$ & & 60 & 100 \\
\hline \multirow{6}{*}{2.} & \multirow{5}{*}{ Usia } & $<20$ tahun & 6 & 10 \\
\hline & & 21-30 tahun & 13 & 21.67 \\
\hline & & 31-40 tahun & 14 & 23.33 \\
\hline & & 41-50 tahun & 19 & 31.67 \\
\hline & & $>50$ tahun & 8 & 13.33 \\
\hline & Jumlah & & 60 & 100 \\
\hline \multirow{6}{*}{3.} & \multirow{5}{*}{ Pendidikan terakhir } & SD & 7 & 11.67 \\
\hline & & SMP/Sederajat & 7 & 11.67 \\
\hline & & SMA/Sederajat & 38 & 63.33 \\
\hline & & Diploma & 3 & 5 \\
\hline & & Sarjana (S1) & 5 & 8.33 \\
\hline & Jumlah & & 60 & 100 \\
\hline \multirow{6}{*}{4.} & \multirow{5}{*}{ Lamanya Bekerja } & $1-5$ tahun & 15 & 25 \\
\hline & & 6-10 tahun & 8 & 13.33 \\
\hline & & 11-15 tahun & 7 & 11.67 \\
\hline & & 16-20 tahun & 6 & 10 \\
\hline & & $>21$ tahun & 24 & 40 \\
\hline & Jumlah & & 60 & 100 \\
\hline
\end{tabular}

Sumber: Data diolah, 2015 
Berdasarkan hasil penelitian dapat diketahui jawaban responden secara rinci mengenani Quality of Work Life seperti yang ditunjukan pada Tabel 4. Quality of Work Life digolongkan pada kriteria baik dengan skor rata-rata jawaban responden yang tertinggi adalah indikator (X.4) sebesar 4,13 yaitu kelompok kerja yang diterapkan oleh Swastika
Bungalows Sanur membantu karyawan dalam melakukan pekerjaannya. Hal ini diikuti dengan gaji atau upah yang diterima karyawan tepat pada waktu yang ditetapkan maka, dapat disimpulkan bahwa Quality of Work Life yang dirasakan karyawan di Swastika Bungalows Sanur masih baik.

Tabel 4. Deskripsi Variabel Quality of Work Life

\begin{tabular}{|c|c|c|c|c|c|c|c|c|}
\hline \multirow{2}{*}{ No } & \multirow{2}{*}{ Pernyataaan } & \multicolumn{5}{|c|}{ Proporsi Jawaban Responden } & \multirow{2}{*}{$\begin{array}{l}\text { Rata- } \\
\text { rata }\end{array}$} & \multirow{2}{*}{ Ket } \\
\hline & & 1 & 2 & 3 & 4 & 5 & & \\
\hline 1. & $\begin{array}{l}\text { Menurut saya, perusahaan mendorong } \\
\text { karyawan untuk memberikan saran } \\
\text { mengenai penanganan suatu masalah. }\end{array}$ & 0 & 3 & 6 & 42 & 9 & 3.95 & Baik \\
\hline 2. & $\begin{array}{l}\text { Menurut saya, karyawan dalam } \\
\text { pengambilan keputusan berguna } \\
\text { dalam meningkatkan hubungan antar } \\
\text { karyawan. }\end{array}$ & 0 & 4 & 5 & 41 & 10 & 3.95 & Baik \\
\hline 3. & $\begin{array}{l}\text { Gaji atau upah yang saya terima tepat } \\
\text { waktu. }\end{array}$ & 0 & 2 & 7 & 37 & 14 & 4.05 & Baik \\
\hline 4. & $\begin{array}{l}\text { System kelompok kerja/workgroup } \\
\text { membantu saya dalam melakukan } \\
\text { pekerjaan. }\end{array}$ & 0 & 1 & 4 & 41 & 14 & 4.13 & Baik \\
\hline 5. & $\begin{array}{l}\text { Lingkungan kerja dapat } \\
\text { membangkitkan semangat kerja saya. }\end{array}$ & 1 & 1 & 13 & 35 & 10 & 3.87 & Baik \\
\hline 6. & Saya merasa keamanan kerja terjamin. & 1 & 2 & 12 & 35 & 10 & 3.85 & Baik \\
\hline & Jumlah & & & & & & 3.97 & Baik \\
\hline
\end{tabular}

Sumber: Data diolah, 2015

Berdasarkan Tabel 5. dapat dijelaskan persepsi responden mengenai motivasi kerja adalah tergolong baik dengan skor rata-rata jawaban responden yang tertinggi adalah indikator (Z.6) sebesar 4,97 yaitu tingginya partisipasi karyawan pada pelatihan dalam meningkatkan kompetensi yang dimiliki karyawan dapat disimpulkan bahwa motivasi kerja karyawan di Swastika Bungalows Sanur masih baik.

Berdasarkan Tabel 6. dapat dikatakan bahwa kepuasan kerja karyawan di Swastika Bungalows Sanur digolongkan pada kriteria baik dengan skor rata-rata jawaban responden yang tertinggi adalah indikator (Y.4) sebesar 3,95 dengan tata letak lingkungan kerja yang nyaman dan diimbangi dengan peralatan kerja yang tersedia memadai yang dapat menunjang pekerjaan karyawan maka, dapat disimpulkan bahwa kepuasan kerja yang dirasakan karyawan di Swastika Bungalows Sanur masih baik.
Pengujian data atau teknik analisis data pada penelitian ini menggunakan teknik analisis jalur (Path Analysis), yaitu perluasan dari analisis regresi linear berganda yang menguji hubungan kausalitas antara 2 atau lebih variabel. Hasil pengujian data menggunakan metode analisis jalur dalam penelitian ini dapat dilihat pada Tabel 7.

Pengaruh variabel secara parsial kriteria pengujian untuk menjelaskan interpretasi pengaruh antar masing-masing variabel yaitu jika Sig.t $<0,05$ maka $\mathrm{H}_{1}$ diterima, sedangkan jika Sig.t $>0,05$ maka $\mathrm{H}_{1}$ ditolak. Berdasarkan hasil analisis pengaruh Quality of Work Life terhadap kepuasan kerja karyawan diperoleh nilai Sig.t sebesar 0,001 dengan nilai koefisien beta sebesar 0,418. Nilai Sig.t 0,001 $<0,05$ mengindikasikan bahwa $\mathrm{H}_{1}$ diterima (pengujian signifikan) yang mempunyai arti bahwa Quality of Work Life berpengaruh positif terhadap kepuasan kerja karyawan di Swastika Bungalows Sanur. 
Tabel 5. Deskripsi Variabel Motivasi Kerja

\begin{tabular}{|c|c|c|c|c|c|c|c|c|}
\hline \multirow{3}{*}{ No } & \multirow{3}{*}{ Pernyataaan } & \multicolumn{5}{|c|}{ Proporsi Jawaban Responden } & \multirow{3}{*}{$\begin{array}{l}\text { Rata- } \\
\text { rata }\end{array}$} & \multirow{3}{*}{ Ket } \\
\hline & & & & & & & & \\
\hline & & 1 & 2 & 3 & 4 & 5 & & \\
\hline 1. & $\begin{array}{l}\text { Saya tiba di perusahaan tepat } \\
\text { waktu. }\end{array}$ & 1 & 3 & 12 & 38 & 6 & 3.75 & Baik \\
\hline 2. & $\begin{array}{l}\text { Pekerjaan yang saya lakukan } \\
\text { menarik. }\end{array}$ & 0 & 6 & 11 & 38 & 5 & 3.70 & Baik \\
\hline 3. & $\begin{array}{l}\text { Saya memikirkan masalah } \\
\text { pekerjaan ketika berada di rumah. }\end{array}$ & 0 & 12 & 15 & 22 & 11 & 3.53 & Baik \\
\hline 4. & $\begin{array}{l}\text { Saya yakin terhadap kemampuan } \\
\text { yang saya miliki untuk berhasil } \\
\text { dalam pekerjaan. }\end{array}$ & 0 & 4 & 10 & 33 & 13 & 3.92 & Baik \\
\hline 5. & $\begin{array}{l}\text { Saya bertanggung jawab terhadap } \\
\text { kesalahan yang saya lakukan. }\end{array}$ & 1 & 0 & 4 & 33 & 22 & 4.25 & Baik \\
\hline 6. & $\begin{array}{l}\text { Saya berpartisipasi pada pelatihan } \\
\text { karyawan untuk meningkatkan } \\
\text { kompentensi yang saya miliki. }\end{array}$ & 0 & 2 & 12 & 32 & 14 & 4.97 & $\begin{array}{c}\text { Sangat } \\
\text { Baik }\end{array}$ \\
\hline & Jumlah & & & & & & 4.02 & Baik \\
\hline
\end{tabular}

Sumber: Data diolah, 2015

Tabel 6. Deskripsi Variabel Kepuasan Kerja Karyawan

\begin{tabular}{|c|c|c|c|c|c|c|c|c|}
\hline \multirow{3}{*}{ No } & \multirow{3}{*}{ Pernyataaan } & \multicolumn{5}{|c|}{ Proporsi Jawaban Responden } & \multirow{3}{*}{$\begin{array}{c}\text { Rata- } \\
\text { rata }\end{array}$} & \multirow{3}{*}{ Ket } \\
\hline & & & & & & & & \\
\hline & & 1 & 2 & 3 & 4 & 5 & & \\
\hline 1. & $\begin{array}{l}\text { Kenaikan gaji yang saya terima berkala } \\
\text { secara teratur. }\end{array}$ & 1 & 3 & 14 & 35 & 7 & 3.73 & Baik \\
\hline 2. & $\begin{array}{l}\text { Tunjangan yang saya dapat sesuai } \\
\text { dengan kebutuhan. }\end{array}$ & 7 & 10 & 15 & 26 & 2 & 3.10 & Cukup \\
\hline 3. & $\begin{array}{l}\text { Saya merasa atasan selalu } \\
\text { mendengarkan permasalahan yang } \\
\text { dihadapi karyawan. }\end{array}$ & 1 & 6 & 16 & 32 & 5 & 3.32 & Cukup \\
\hline 4. & $\begin{array}{l}\text { Saya merasa tata letak lingkungan kerja } \\
\text { nyaman }\end{array}$ & 0 & 2 & 7 & 43 & 8 & 3.95 & Baik \\
\hline 5. & $\begin{array}{l}\text { Saya merasa hubungan antar karyawan } \\
\text { terjalin akrab. }\end{array}$ & 0 & 2 & 16 & 32 & 10 & 3.83 & Baik \\
\hline 6. & $\begin{array}{l}\text { Saya merasa peralatan kerja yang } \\
\text { tersedia sangat memadai dapat } \\
\text { menunjang pekerjaan. }\end{array}$ & 1 & 2 & 10 & 37 & 10 & 3.88 & Baik \\
\hline & Jumlah & & & & & & 3.64 & Baik \\
\hline
\end{tabular}

Sumber : Data diolah, 2015 
Tabel 7. Pengaruh Langsung dan Pengaruh Tidak Langsung serta Pengaruh Total Quality of Work Life (X), Motivasi Kerja (Z) dan Kepuasan Kerja Karyawan (Y)

\begin{tabular}{cccc}
\hline & & Pengaruh Tidak Langsung Melalui Motivasi & \\
Pengaruh & Pengaruh & Kerja & Pengaruh \\
Variabel & Langsung & $(\mathrm{Z})(\beta 2 \times \beta 3)$ & Total \\
\hline $\mathrm{X} \rightarrow \mathrm{Z}$ & 0,518 & - & 0,518 \\
$\mathrm{X} \rightarrow \mathrm{Y}$ & 0,418 & 0,140 & 0,558 \\
$\mathrm{Z} \rightarrow \mathrm{Y}$ & 0,270 & - & 0,270 \\
\hline
\end{tabular}

Sumber : Data diolah, 2015

Tabel 8. Hasil Analisis Jalur Persamaan Regresi 1

\begin{tabular}{|c|c|c|c|c|c|c|}
\hline \multirow{2}{*}{\multicolumn{2}{|c|}{ Model }} & \multicolumn{2}{|c|}{ Unstandardized Coefficients } & \multirow{2}{*}{$\begin{array}{c}\begin{array}{c}\text { Standardized } \\
\text { Coefficients }\end{array} \\
\text { Beta }\end{array}$} & \multirow[b]{2}{*}{$\mathrm{t}$} & \multirow[b]{2}{*}{ Sig. } \\
\hline & & $\mathrm{B}$ & Std. Error & & & \\
\hline \multirow[t]{2}{*}{1} & (Constant) & 7.665 & 3.325 & & 2.305 & .025 \\
\hline & $\begin{array}{l}\text { Quality of work } \\
\text { life }\end{array}$ & .639 & .139 & .518 & 4.608 & .000 \\
\hline & $: 0,268$ & & & & & \\
\hline & $\begin{array}{ll}\text { tistik } & : 21,232 \\
G & : 0,000\end{array}$ & & & & & \\
\hline
\end{tabular}

Sumber : Data diolah, 2015

Tabel 9. Hasil Analisis Jalur Persamaan Regresi 2

\begin{tabular}{|c|c|c|c|c|c|c|}
\hline \multirow[b]{2}{*}{ Model } & & \multicolumn{2}{|c|}{ Unstandardized Coefficients } & \multirow{2}{*}{$\begin{array}{c}\text { Standardized } \\
\text { Coefficients }\end{array}$} & \multirow[b]{2}{*}{$\mathrm{t}$} & \multirow[b]{2}{*}{ Sig. } \\
\hline & & $\mathrm{B}$ & Std. Error & & & \\
\hline \multirow[t]{3}{*}{1} & (Constant) & 2.324 & 3.485 & & .667 & .508 \\
\hline & $\begin{array}{l}\text { Quality of work } \\
\text { life }\end{array}$ & .551 & .163 & .418 & 3.384 & .001 \\
\hline & Motivasi Kerja & .288 & .132 & .270 & 2.185 & .033 \\
\hline $\mathrm{R}^{2}$ & $: 0,364$ & & & & & \\
\hline $\begin{array}{l}\text { F Statistik } \\
\text { Sig. F }\end{array}$ & $\begin{array}{c}: 16,311 \\
\mathrm{k} \\
: 0,000\end{array}$ & & & & & \\
\hline
\end{tabular}

Sumber: Data diolah, 2015

Berdasarkan hasil analisis pengaruh Quality of Work Life terhadap motivasi kerja diperoleh nilai Sig.t sebesar 0,000 dengan nilai koefisien beta sebesar 0,518. Kesimpulannya adalah nilai Sig.t $0,000<0,05$ mengindikasikan bahwa $\mathrm{H}_{0}$ ditolak dan $\mathrm{H}_{1}$ diterima, yang mempunyai arti bahwa Quality of Work Life berpengaruh positif terhadap motivasi kerja di Swastika Bungalows Sanur.

Berdasarkan hasil analisis pengaruh motivasi kerja terhadap kepuasan kerja karyawan diperoleh nilai Sig.t sebesar 0,033 dengan nilai koefisien beta sebesar 0,270.
Kesimpulannya $\mathrm{H}_{1}$ diterima, yang mempunyai arti bahwa motivasi kerja berpengaruh postif terhadap kepuasan kerja karyawan di Swastika Bungalows Sanur.

Uji sobel digunakan dengan menguji kekuatan pengaruh tidak langsung variabel Quality Of Work Life (X) terhadap kepuasan kerja karyawan (Y) melalui variabel motivasi kerja (Z). Untuk menguji pengaruh tidak langsung maka nilai $\mathrm{z}$, terlebih dahulu dihitung koefisien ab dengan rumus sebagai berikut:

$$
\begin{aligned}
& a b=0,639 \times 0,288 \\
& a b=0,18403
\end{aligned}
$$


Berdasarkan diagram jalur pengaruh tidak langsung tersebut, maka dapat dihitung Standar error koefisien a dan $b$ ditulis dengan $S_{a}$ dan $S_{b}$, besarnya stanar error tidak langsung (indirect effect) $\mathrm{S}_{\mathrm{ab}}$ dihitung dengan rumus sebagai berikut :

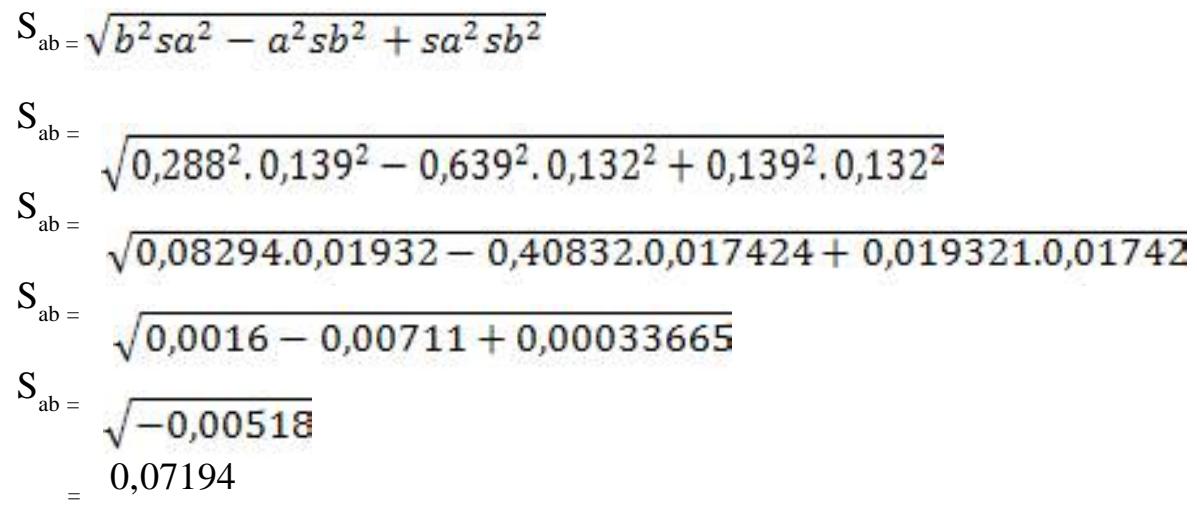

Dalam menguji nilai $\mathrm{z}$ dapat dihitung dengan rumus sebagai berikut:

$$
\begin{aligned}
& \mathrm{z}=\frac{a b}{s_{a b}} \\
& \mathrm{z}=\frac{0,18403}{0,07194} \\
& \mathrm{z}=2,558129=2,56
\end{aligned}
$$

Berdasarkan hasil perhitungan didapatkan perbandingan nilai $\mathrm{z}$ hitung sebesar dan $\mathrm{z}$ tabel sebesar $(2,56>1,96)$ sehingga dapat disimpulkan bahwa $\mathrm{H}_{1}$ diterima, artinya peran motivasi kerja secara positif memediasi pengaruh Quality of Work Life terhadap kepuasan kerja karyawan.

\section{Pengaruh Quality Of Work Life Terhadap Kepuasan Kerja Karyawan}

Hasil penelitian menunjukan bahwa Quality of Work Life berpengaruh positif terhadap kepuasan kerja karyawan di Swastika Bungalows Sanur Hal ini juga dibuktikan dengan penelitian sebelumnya yang menyebutkan bahwa meningkatnya kepuasan kerja diimbangi dengan meningkatnya kondisi kerja, kesejahteraan umum, keseimbangan kehidupan kerja dan prospek karir, kompensasi serta pelatihan dan pengembangan (Swapna \& Gomathi, 2013). Hasil penelitian ini juga mendukung penelitian sebelumnya bahwa suasana kerja akan menciptakan kualitas kehidupan kerja yang kondusif bagi tercapainya tujuan organisasi dimana peningkatan Quality of Work Life dapat memiliki dampak positif pada peningkatan kepuasan kerja terhadap organisasi (Paseki, 2013). Implikasi dari penelitian ini yaitu Quality of Work Life yang diterapkan oleh Swastika Bungalows sanur dapat meningkatkan kepuasan kerja karyawan di Swastika Bungalows Sanur, artinya semakin tinggi Quality of Work Life yang diterapkan maka semakin tinggi pula kepuasan kerja karyawan tersebut. Swastika Bungalows Sanur menerapkan sistem gaji berdasarkan persentase tingkat kehadiran karyawan, maka dari itu rata-rata persentase tingkat kehadiran karyawan di Swastika Bungalows Sanur sangat tinggi. Kompensasi yang diterima karyawan harus sesuai dengan pekerjaan yang dilakukan selain mengacu pada tingkat kehadiran, kompensasi juga harus mengacu pada Upah Minimum Regional.

\section{Pengaruh Quality Of Work Life Terhadap Motivasi Kerja}

Secara keseluruhan Quality Of Work Life berpengaruh langsung dan signifikan terhadap motivasi kerja dimana Quality Of Work Life yang baik akan meningkatkan motivasi kerja dan kinerja pekerja dan diharapkan setiap pekerja mau bekerja keras dan antusias untuk mencapai produktivitas kerja yang tinggi (Aryansah, 2012). Hasil penelitian menunjukan bahwa Quality of Work Life berpengaruh positif terhadap motivasi kerja di Swastika Bungalows Sanur. Hasil penelitian ini berarti mendukung penelitian sebelumnya yaitu Quality of Work Life berpengaruh secara 
signifikan terhadap motivasi kerja yang dibuktikan dengan hasil penelitian secara simultan (Yasa, 2007). Implikasi penelitian ini yaitu Quality of Work Life yang diterapkan oleh Swastika Bungalows sanur dapat meningkatkan motivasi kerja karyawan di Swastika Bungalows Sanur, artinya semakin tinggi Quality of Work Life yang diterapkan maka semakin tinggi pula motivasi kerja karyawan di Swastika Bungalows Sanur.

\section{Pengaruh Motivasi Kerja Terhadap Kepuasan Kerja}

Hasil penelitian menunjukan bahwa motivasi kerja berpengaruh positif terhadap kepuasan kerja karyawan di Swastika Bungalows Sanur. Hasil penelitian ini mendukung penelitian sebelumnya dimana motivasi kerja berpengaruh secara signifikan terhadap kepuasaan kerja pegawai dimana untuk tetap mempertahankan dan terus meningkatkan motivasi pada pegawainya seperti pemenuhan kebutuhan dan keinginan yang sesuai harapan, fasilitas kerja terpenuhi, hubungan baik dengan rekan sekerja, serta keamanan di lingkungan kerja dalam menciptakan kepuasaan kerja yang lebih tinggi dari sebelumnya (Murti \& Srimulyani, 2013). Implikasi penelitian ini yaitu Motivasi kerja yang dirasakan karyawan Swastika Bungalows sanur dapat meningkatkan kepuasan kerja karyawan di Swastika Bungalows Sanur, artinya semakin tinggi motivasi kerja yang dirasakan karyawan maka semakin tinggi pula kepuasan kerja karyawan tersebut.

\section{Peran Motivasi Kerja Dalam Memediasi Pengaruh Quality Of Work Life Terhadap Kepuasan Kerja Karyawan}

Hasil penelitian menunujukan bahwa peran motivasi kerja secara positif memediasi pengaruh Quality of Work Life terhadap kepuasan kerja karyawan di Swastika Bungalows Sanur. Budiyanto (2011) juga mendukung pernyataan ini, dimana motivasi kerja dapat menjadi variabel yang memediasi terhadap kepuasan kerja karyawan. Jika motivasi diberikan secara tepat, akan dapat mendorong karyawan untuk lebih meningkatkan kinerjanya sehingga dapat meraih tujuan pribadi maupun target institusi yang akan berpengaruh terhadap kepuasan diri karena pencapaian yang telah mereka raih (Aslam dkk, 2013). Berdasarkan hasil penelitian yang didukung dengan penelitian sebelumya maka terdapat implikasi bahwa Quality of Work Life berpengaruh terhadap kepuasan kerja karyawan melalui motivasi kerja, artinya semakin tinggi Quality of Work Life yang diterapkan
Swastika Bungalows Sanur maka semakin tinggi motivasi kerja yang dirasakan karyawan tersebut yang mana akan meningkatkan kepuasan kerja karyawan di Swastika Bungalows Sanur.

\section{SIMPULAN DAN SARAN Simpulan}

Berdasarkan hasil pembahasan pada bab sebelumnya, dapat ditarik beberapa simpulan yaitu pertama, Quality of Work Life berpengaruh positif terhadap kepuasan kerja karyawan. Pengaruh positif dapat diartikan bahwa semakin tinggi Quality of Work Life yang diterapkan Swastika Bungalows Sanur maka semakin tinggi pula kepuasan kerja yang dirasakan karyawan.

Kedua, Quality Of Work Life berpengaruh positif terhadap motivasi kerja. Pengaruh positif dapat diartikan bahwa semakin tinggi Quality of Work Life yang diterapkan Swastika Bungalows Sanur maka semakin tinggi pula motivasi kerja karyawan.

Ketiga, motivasi kerja berpengaruh positif terhadap kepuasan kerja karyawan. Pengaruh positif dapat diartikan bahwa semakin tinggi motivasi kerja karyawan maka semakin tinggi pula kepuasan kerja karyawan di Swastika Bungalows Sanur.

Keempat, motivasi kerja mampu memediasi pengaruh Quality Of Work Life terhadap Kepuasan kerja karyawan. Peran motivasi kerja berpengaruh positif dalam memediasi pengaruh Quality Of Work Life terhadap kepuasan kerja karyawan. Pengaruh positif dapat diartikan bahwa semakin tinggi Quality Of Work Life yang diterapkan Swastika Bungalows Sanur maka semakin tinggi pula motivasi kerja karyawan di Swastika Bungalows Sanur yang akan meningkatkan kepuasan kerja karyawan di Swastika Bungalows Sanur.

\section{Saran}

Berdasarkan hasil simpulan, maka saran yang dapat diberikan kepada pihak Swastika Bungalows Sanur adalah pertama, perusahaan harus meningkatkan keamanan kerja karyawan. Peningkatan keamanan kerja dimaksudkan untuk melindungi para karyawan ketika sedang bekerja dan dapat melindungi asset atau fasilitas yang dimiliki perusahaan. Keamanan kerja yang terjamin akan dapat mendukung terciptanya suasanan kerja yang baik, aman dan nyaman bagi karyawan.

Kedua, untuk mengurangi beban terhadap karyawan sebaiknya perusahaan memberikan kebebasan kepada karyawan sehingga karyawan mampu menyelesaikan pekerjaan sesulit atau 
seberat apapun dengan keadaan suasana kerja yang nyaman. Rasa nyaman dan puas karena dapat menyelesaikan pekerjaan sesuai keinginan dengan cara sendiri tetapi masih tetap sesuai dengan peraturan yang telah ditentukan perusahaan dapat membantu mengurangi beban pikiran karyawan ketika karyawan berada dirumah.

Ketiga, perusahaan sebaiknya meningkatkan kesejahteraan karyawan melalui peningkatan dalam pemberian insentif bagi karyawan seperti tunjangan kerja yang sesuai dengan kebutuhan karyawan, karena dengan pemberian insentif yang sesuai karyawan dapat merasakan timbal balik antara perusahaan dengan karyawan. Apabila karyawan merasa dihargai oleh perusahaan maka dapat meningkatkan kepuasan kerja yang akan berdampak pada produktivitas perusahaan.

\section{REFERENSI}

Anatan, L., dan Lena, E. 2007. Manajemen Sumber Daya Manusia dalam Bisnis Modern. Alfabeta Bandung.

Arifin, N. 2012. Analisis Kualitas Kehidupan Kerja, Kinerja, Dan Kepuasan Kerja Pada CV Duta Senenan Jepara. Jurnal Economia, Volume 8, Nomor 1, April 2012 11-21.

Aryansah, I. 2012. Iklim Organisasi Dan Kualitas Kehidupan Kerja Karyawan. Skripsi. Universitas Islam Negeri Sunan Kalijaga.

Aryansah, I., dan Erika S. K. 2013. Iklim Organisasi Dan Kualitas Kehidupan Kerja Karyawan. Jurnal Humanitas, Vol.X, No.1.

Aslam, A., Asri L. R., dan Gunawan P. W. 2013. Pengaruh Perilaku Kerja, Lingkungan Kerja, Dan Interaksi Sosial Terhadap Kepuasan Kerja Dengan Motivasi Sebagai Variabel Pemediasi (Studi Pada Staf Rumah Sakit Umum Daerah Pandan Arang Boyolali). Prosiding Seminar Nasional Perkembangan Terkini Sains Farmasi Dan Klinik Iii. Issn: 2339-2592

Budiyanto. 2011. The Effect of Job Motivation, Work Environment and Leadership on Organizational Citizenship Behavior, Job Satisfaction and Public Service Quality in Magetan, East Java, Indonesia. World Academy of Science, Engineering and Technology 51.

Chandranshu, S. 2012. Factors Affecting Quality Of Work Life: Empirical Evidence From Indian Organizations. Australian Journal of Business and Management Research, Vol.1 No.11, 31-40.

Davis, N. 2006. Perilaku Dalam Organisasi, Erlangga, Jakarta.
Fitriadi, B. Y. 2011. Analisis Pengaruh Kualitas Kehidupan Kerja Terhadap Motivasi Kerja Dan Kinerja Karyawan PT. Bank Muamalat Indonesia Jember. Skripsi. Fakultas Ekonomi Universitas Jember.

Ghozali, I. 2011. Aplikasi Analisis Multivariate dengan Program IBM SPSS19, Badan Penerbit Universitas Diponegoro, Semarang.

Idrus, M. 2006. Implikasi Organisasi Terhadap Kepuasan Kerja Dan Kualitas Kehidupan Kerja Karyawan. Jurnal Psikologi Universitas Diponogoro, Vol. 3 No. 1: 94-106.

Istijanto, O. 2010. Riset Sumber Daya Manusia. Jakarta : PT. Gramedia Pustaka. Utama.

Kermansaravi, F., Ali N., Shahindokht N. R., and Fariba Yaghoubinia. 2015. The Relationship Between Quality Of Work Life And Job Statisfaction Of Faculty Members In Zahedan University Of Medical Sciences. Global Journal Of Health Sciences, Vol.7, No.2.

Khorsandi, M., Jahani, F., Rafie, M., and Farazi, A. 2010. Health - Related Quality Of Life In Staff And Hospital Personnel Of Arak University Of Medical Sciences In 2009. Journal Of Arak Medical University, Vol.13, No.1, 40-48 (Persian).

Lau, R. S. M. and Anderson, C. A. 1998. A ThreeDimensional Perspective Of Total Quality Management. International Journal of Quality \& Reliability Management, Vol. 15 No. 1, Pp. 85-98.

Murti, H., dan Veronika A. S. 2013. Pengaruh Motivasi Terhadap Kinerja Pegawai Dengan Variabel Pemediasi Kepuasan Kerja Pada PDAM Kota Madiun. Jurnal Riset Manajemen \& Akuntansi, Vol. 1 No. 1.

Murtinigrum, D. 2011. Analisis Faktor-Faktor Yang Mempengaruhi Kepuasan Kerja Karyawan Pada PT. Bank OCBC NISP Tbk. Thesis. Magister Manajemen Universitas Sumatra Utara.

Nekouei. 2014. Quality of Work Life and Job Satisfaction among Employee in Government Organizations in IRAN. Journal of Basic and Applied, Vol.4,No.1

Paseki, F. M. 2013. Kualitas Kehidupan Kerja Dan Kinerja Karyawan Terhadap Pengembangan Karir Pada Kanwil Direktorat Jendral Kekayaan Negara Suluttenggo Malut Di Manado. Jurnal EMBA, Vol.1, No.4, Hal. 1240-1249. ISSN 2303-1174.

Pramdhana, F. 2013. Pengaruh Quality Of Work Life (QWL) Terhadap Kepuasan Kerja Karyawan Pada PT. Sumber Murni Lestari Makasar. 
Skripsi. Jurusan Manajemen Fakultas Ekonomi Dan Bisnis Universitas Hasanuddin.

Rahmawati, D. 2013. Pengaruh Motivasi Terhadap Produktivitas Kerja Karyawan PR Fajar Berlian Tulungagung. Jurnal Universitas Tulung agung Bonoworo, Vol 1 No. 1.

Riduwan. 2012. Dasar - Dasar Statistika. Cetakan kesepuluh. Bandung: Alfabeta

Robbins S. P., dan Timothy. 2013. Organizational Of Bahvior. $8^{\text {th }}$ Edition, Mcgraw-Hill, Irwin.

Rokhman, W. 2012. Pengaruh QWL terhadap Kepuasan Kerja, Komitmen Organisasi, Turnover Intention dan Stres Kerja: Studi pada BMT di Kabupaten Kudus. Skripsi. Sekolah Tinggi Agama Islam Negeri (STAIN) Kudus. Jawa Timur.

Sugiyono, 2014. Metode Penelitian Bisnis Kuantitatfi, Kualitatif dan $R \& D$. Bandung: CV Alfabeta.

Suharso, P. 2010. Model Analisis Kuantitatif "TEV". Jakarta: Indeks

Sunyoto. 2013. Manajemen Sumber Daya Manusia. Jakarta: PT Indeks.

Swapna, M., and Gomathi. 2013. A Study On The Interplay Between The Constructs Of Quality Of Work Life: With Special Reference To IT
Profesionals In Bangalore City. Asian Social Sciences, Vol.9, No.9, Pp.107-122.

Teck-Hong, T., and Waheed, A. 2011. Herzberg's Motivation-Hygiene Theory And Job Satisfaction In The Malaysian Retail Sector: The Mediating Effect Of Love Of Money. Asian Academy Of Management Journal, Vol.16, No.1.

Umar, H. 2008. Desain Penelitian MSDM dan Perilaku Karyawan. Jakarta : PT Raja Grafindo Persada.

Veithsal, R., dan Deddy. 2011. Kepemimpinan dan Perilaku Organisasi. PT. Raja Grafindo Persada: Jakarta Walton, R. E. (1973). Quality Of Work Life, What Is It?. Sloan Management Review Journal, 11-21.

Walton, R. E. 1998. Quality Of Work Life, What Is It?. Sloan Management Review Journal, 11-21.

Yasa, I. K. 2007. Pengaruh Quality of Work Life (QWL) Terhadap Motivasi dan Kinerja Karyawan. Jurnal Bisnis dan Kewirausahaan, Vol.3, No. $2: 75-82$

Yusuf, T. 2010. Pengaruh Kualitas Kehidupan Kerja, Komitmen Kerja, dan Motivasi terhadap Kepuasan Kerja (Studi Kasus Karyawan PDAM Balikpapan). Jurnal Ekonomi Universitas Balikpapan. 